\title{
NACIONALIDADE DA SOCIEDADE E LEI APLICÁVEL
}

\section{NATIONALITY OF CORPORATIONS AND APPLICABLE LAW}

\author{
${ }^{1}$ Alexandre Ferreira de Assumpção Alves \\ ${ }^{2}$ Raphael Vieira da Fonseca Rocha
}

\section{RESUMO}

O trabalho investiga, através do método dedutivo e pesquisa do tipo bibliográfica, o tema da nacionalidade das sociedades e a lei aplicável a suas relações jurídicas. Primeiramente, examina conceitos básicos como pessoa jurídica, personalidade jurídica, empresa e sociedade empresária. Depois, volta-se à análise do conceito de nacionalidade e dos principais critérios adotados pelos Estados para atribuir nacionalidade a uma determinada sociedade. Segue com uma investigação do ordenamento brasileiro como um todo, a fim de demonstrar quais foram os critérios incorporados pelo Brasil. Ato contínuo, dedica-se aos critérios existentes de eleição da lei aplicável às relações jurídicas das sociedades e a opção feita pelo ordenamento brasileiro. Finalmente, analisam-se casos concretos na jurisprudência internacional, com o escopo de chamar atenção do leitor sobre a importância prática do tema.

Palavras-chave: Nacionalidade, Pessoa jurídica, Sociedades, Lei aplicável, Critérios

\section{ABSTRACT}

The paper investigates, through the deductive method and bibliographic-based research, the subject of nationality of corporations and the applicable law to their legal relations. Firstly, it examines basic concepts as legal entities, legal personality, entrepreneurial activity and entrepreneurial corporation. After this, it turns to the analysis of the concept of nationality and the main criteria adopted by the States to attribute nationality to a particular corporation. It follows with an investigation of the Brazilian legal system as a whole, in order to demonstrate which criteria were incorporated by Brazil. Thereafter, it devotes to the existing criteria of choice of applicable law to the corporations legal relations and the option made by Brazilian legal system. Finally, it analyses some practical cases in international case law, with the scope to draw the readers attention on the practical importance of this subject.

Keywords: Nationality, Legal entity, Corporations, Applicable law, Criteria

\footnotetext{
${ }^{1}$ Doutor na Universidade do Estado do Rio de Janeiro - UERJ, Rio de Janeiro, RJ, (Brasil). Professor na Universidade Federal do Estado do Rio de Janeiro, UNIRIO, Rio de Janeiro, RJ.E-mail: asaa@ uol.com.br. ${ }^{2}$ Mestrando em Direito na Universidade do Estado do Rio de Janeiro, UERJ, Rio de Janeiro, RJ, (Brasil). E-mail: raphael_rocha_16@hotmail.com.
} 


\section{INTRODUÇÃO}

A sociedade atual e os indivíduos encontram-se cada vez mais interligados pela globalização. Pessoas físicas e jurídicas não se limitam tão somente às fronteiras de seus países. O desenvolvimento surpreendente da tecnologia da informação permite que o capital assuma uma feição transnacional, fluindo os investimentos e desinvestimentos livremente pelos Estados e continentes, podendo o investidor aportar recursos em qualquer parte e mediante constituição de qualquer forma jurídica. Com efeito, observa-se uma proliferação de investimentos em territórios estrangeiros, sobretudo em "paraísos fiscais". Sociedades empresárias ${ }^{1}$ estabelecem relações em vários países; entes coletivos têm sede instalada em um Estado e filial (is) em território de outro (s); grandes conglomerados empresariais podem ser comandados de qualquer lugar do mundo dada facilidade de deslocamento e comunicação.

Neste contexto de circulação massiva e praticamente "instantânea" de capital, situa-se o Estado soberano. Se ele necessita, por um lado, atrair investimentos das sociedades empresárias, a fim de promover seu desenvolvimento socioeconômico, por outro lado, é necessário preservar-se diante de eventuais infortúnios que o capital fugaz pode lhe ocasionar $^{2}$. A relação simbiótica entre Estado e sociedades, em decorrência da diferença de cultura, costumes e legislações de cada Nação, acaba gerando conflitos de ordem nacional e/ou internacional, que precisam ser solucionados pelo direito.

O presente trabalho pretende analisar uma primordial questão jurídica dessa relação, isto é, os critérios de atribuição de nacionalidade às sociedades empresárias, tanto os previstos pelas normas internas quanto pelas convencionais, bem como analisar qual lei deverá o Estado-juiz aplicar aos vários aspectos da vida desses entes coletivos em eventuais litígios. Além disso, terá por escopo abordar as principais teorias propostas pela doutrina e, após, reconhecer quais delas foram adotadas pela legislação brasileira, tanto em sede constitucional quanto infraconstitucional. O interesse pelo tema não se cinge apenas ao plano teórico, uma vez que inúmeras são suas consequências práticas ${ }^{3}$. Algumas indagações interessantes podem surgir ao se refletir sobre a relação entre Estados e entes coletivos:

\footnotetext{
${ }^{1}$ Com a entrada em vigor do Código Civil de 2002, adotou-se no Brasil a teoria da empresa. Em razão disso, ao longo desse trabalho, o termo "empresa" será utilizado apenas no sentido técnico de objeto de direito, isto é, atividade empresária. Para a pessoa jurídica, sujeito de direito, que exerce empresa, será adotado o termo "sociedade".

2 Os impactos decorrentes da entrada e saída de capital estrangeiro surtem seus efeitos em variados campos. Como exemplo, cita-se: impacto direto no mercado de capitais (variações nos índices das bolsas de valores); mercado financeiro (aumento da inflação e das taxas de juros) e cambiário (desvalorização da moeda nacional).

${ }^{3}$ Para uma leitura aprofundada sobre o tema, consulte: VAGTS, Detley F.; DODGE, William S.; KOH, Harold
} 
E se grupos ligados a "nações inimigas" [...] adquirissem o comando acionário das grandes companhias fornecedoras de armamentos ao governo americano? E se fundos chineses ou indianos adquirissem o comando acionário de empresas [sic] de alta tecnologia dos EUA, do Japão ou da Europa, detentoras de concorridíssimos "segredos"? E se grandes companhias do "norte" adquirissem o capital de sociedades brasileiras - ou mesmo as criassem - para comprar e explorar amplas extensões de terras da Amazônia? ${ }^{4}$

O método empregado é o dedutivo, partindo-se da análise dos critérios da lei brasileira para a nacionalidade das sociedades para expor normas jurídicas e doutrina sobre o tema, produzindo uma conclusão pessoal com supedâneo nas premissas adotadas no material investigatório coligado. Também se almeja apresentar semelhanças e/ou diferenças entre as teorias adotadas por outros ordenamentos sobre a fixação da nacionalidade da sociedade e lei aplicável, bem como analisar famosos precedentes judiciais internacionais.

\section{CONSIDERAÇÕES SOBRE A PESSOA JURÍDICA E SUA PERSONALIDADE JURÍDICA}

O homem é um ser eminentemente social, não sendo de sua natureza viver isolado, mas em grupos. Desse convívio, surge a necessidade de regular a comunidade por determinadas normas de conduta. Ensina a doutrina ${ }^{5}$ que o objetivo do direito é estabelecer regras que permitam ao ser humano o convívio em sociedade. Desta ânsia de interesses e benefícios das pessoas por união resultam também algumas unidades coletivas, criadas pela vontade do homem ou em decorrência do curso natural da história. O direito optou por discipliná-las e, assim, permitir que atuem no seio social como legítimos sujeitos de direito, dotados de personalidade própria, a semelhança do ser humano. Tais uniões podem ser de pessoas (universitas personarum) ou destinação de patrimônio a um fim (universitas rerum).

Conforme leciona Carlos Roberto Gonçalves, a razão de ser dessas entidades

[...] está na necessidade ou conveniência de os indivíduos unirem esforços e utilizarem recursos coletivos para a realização de objetivos comuns, que transcendem as possibilidades individuais. Essa constatação motivou a organização de pessoas e bens, com o reconhecimento do direito, que atribui personalidade ao

\footnotetext{
Hongju. Transnational Business Problems, $4^{\text {th }}$ edition, University Casebook Series, Thomson/Foundation Press, 2008.

${ }^{4}$ EMENDÖRFER NETO, Victor. A Nacionalidade das Corporações: Estudo do vínculo entre os Estados e os entes econômicos no contexto das relações internacionais. Trabalho publicado nos Anais do XVII Congresso Nacional do CONPEDI, realizado em Brasília - DF, nos dias 20, 21, e 22 de novembro de 2008. Disponível em: $<$ http://www.conpedi.org.br/manaus/arquivos/anais/brasilia/16_624.pdf $>$. Acesso em: 20.03.2015.

${ }_{5}^{5}$ MAZEAUD, Henri; MAZEAUD, Léon; MAZEAUD, Jean. Leçons de droit civil. v. 1, t. 1; 1973, v. 1, t. 2. Paris: Ed. Montchrestien, 1969 apud GONÇALVES, Carlos Roberto. Direito Civil Brasileiro. Vol. 1, 8. ed., São Paulo: Saraiva, 2010, p. 19.
} 
grupo, distinta de cada um de seus membros, passando este a atuar na vida jurídica com personalidade própria. ${ }^{6}$

No Brasil, de acordo com o atual Código Civil, as pessoas jurídicas podem ser classificadas como de direito público, externo ou interno, e de direito privado (art. 40). As pessoas jurídicas de direito público externo são os Estados soberanos estrangeiros e aquelas que estão sob o manto do Direito Internacional Público (art. 42), como, por exemplo, a Organização das Nações Unidas (ONU). Já as pessoas de direito público interno, são as que compõem os entes da federação, isto é, a União, os Estados, o Distrito Federal, os Territórios e os Municípios, bem como as autarquias e as demais entidades de caráter público criadas pela lei (art. 41), como as fundações públicas. As pessoas jurídicas de direito privado, por sua vez, são as associações, as sociedades, as fundações, as organizações religiosas, os partidos políticos (art. 44) e as empresas individuais de responsabilidade limitada (EIRELI) ${ }^{7}$.

Percorreu-se uma longa trajetória até que as pessoas jurídicas passassem a ser consideradas como efetivos sujeitos de direito, dotadas de personalidade própria. A partir de fins do século XVIII até meados do século XX, verificou-se uma extensa discussão entre os juristas acerca da essência e natureza jurídica da pessoa jurídica. Diversas teorias surgiram para explicar o fenômeno. Não é objetivo do artigo aprofundar este interessante e já explorado assunto, cabendo destacar tão somente os dois principais grupos das teorias clássicas que tiveram maior repercussão na doutrina, quais sejam: teorias da ficção e teorias da realidade.

Possuindo raízes no direito canônico do século XIII e tendo como um de seus formuladores Friedrich Karl Von Savigny, a concepção ficcionista teve seu principal berço na Alemanha e foi largamente utilizada em países como França, Bélgica, Itália e Reino Unido ${ }^{8}$.

Em linhas gerais, a teoria da ficção advoga que apenas os seres humanos são sujeitos da relação jurídica e titular de direitos subjetivos porque a personalidade lhes é inerente. No entanto, opta o ordenamento jurídico por criar, através de suas leis, seres artificiais, por mera fictio juris, dotando-os de capacidade jurídica. Em outros termos, a pessoa jurídica é uma ficção em razão de não possuir as qualidades inerentes à pessoa natural, como os sentimentos, a inteligência, o intelecto, entre outros. A teoria divide esses entes em pessoas jurídicas

\footnotetext{
${ }^{6}$ GONÇALVES, Carlos Roberto. Direito Civil Brasileiro. v.1, 8. ed., São Paulo: Saraiva, 2010, p. 215. Sobre o tema, veja-se também: WALD, Arnold. Curso de direito civil brasileiro. Introdução e parte geral, v. 1, 9. ed. São Paulo: Saraiva, 2002, p. 146; AMARAL, Francisco, Direito Civil. Introdução, 4. ed. Rio de Janeiro: Renovar, 2002, p. 269-270; MIRANDA, Francisco Cavalcanti Pontes de. Tratado de direito privado, v. 1, 3. ed. Rio de Janeiro: Borsoi, 1954/1956, v.8, p. 280.

${ }^{7}$ Atual figura empresária criada pela lei no 12.441/2011.

${ }^{8}$ RODAS, João Grandino. Sociedade Comercial e Estado. São Paulo: Saraiva, 1995, p. 19.
} 
necessárias, como a figura do Estado, e artificiais ou arbitrárias, que é o caso, verbi gratia, das sociedades empresárias.

Conforme lição de Theophilo de Azeredo Santos, caso a concepção ficcionista seja levada ao extremo, pode-se chegar à conclusão de que não é atribuível à pessoa jurídica nacionalidade, uma vez que esta seria qualidade inerente apenas às pessoas naturais, que são as únicas passíveis de sentir amor e gratidão pela Pátria ${ }^{9}$. O referido jurista, em crítica a este posicionamento, destaca que o seu grande equívoco se situa na crença de que "o laço de nacionalidade ocasiona, sempre, as mesmas consequências" para pessoas naturais e jurídicas ${ }^{10}$. Será exposto adiante o conceito de nacionalidade e as consequências que surgem no campo da lei aplicável com sua atribuição a determinadas sociedades empresárias.

De acordo com Carlos Roberto Gonçalves:

As teorias da ficção não são, hoje, aceitas. A crítica que se lhes faz é a de que não explicam a existência do Estado como pessoa jurídica. Dizer-se que o Estado é uma ficção legal ou doutrinária é o mesmo que dizer que o direito, que dele emana, também o é. Tudo quanto se encontre na esfera jurídica seria, portanto, uma ficção, inclusive a própria teoria da pessoa jurídica. ${ }^{11}$

Já os defensores das teorias da realidade argumentam que a pessoa jurídica não é uma mera ficção, mas uma realidade viva, com existência própria, tal como são os seres humanos. Para se deduzir tal conclusão, diversas construções foram arquitetadas pelos juristas ${ }^{12}$, importando ao presente trabalho tão somente destacar a teoria da realidade técnica, que foi a adotada pelo Código Civil de 2002. Recorre-se, novamente, à doutrina supracitada:

\begin{abstract}
Entendem seus adeptos [da teoria da realidade técnica], especialmente SALEILLES e COLIN e CAPITANT, que a personificação dos grupos sociais é expediente de ordem técnica, a forma encontrada pelo direito para reconhecer a existência de grupos de indivíduos, que se unem na busca de fins determinados. A personificação é atribuída a grupos que a lei reconhece vontade e objetivos próprios. O Estado, reconhecendo a necessidade e a conveniência de que tais grupos sejam dotados de personalidade própria, para poder participar da vida jurídica nas mesmas condições das pessoas naturais, outorga-lhes esse predicado.

A personalidade jurídica é, portanto, um atributo que o Estado defere a certas entidades havidas como merecedoras dessa benesse. O Estado não outorga esse benefício de maneira arbitrária, mas sim tendo em vista determinada situação, que já encontra devidamente concretizada, e desde que se observem determinados requisitos por ele estabelecidos. 13
\end{abstract}

\footnotetext{
SANTOS, Theophilo de Azeredo. Regime Jurídico das Sociedades Comerciais. Rio de Janeiro: Forense, 1958, p. 27 apud PAULS, Manfred. A nacionalidade e a lei aplicável à pessoa jurídica de direito privado. Dissertação de mestrado apresentada como requisito parcial para obtenção de grau do Programa de Pós-Graduação em Direito Econômico e Social da Pontifícia Universidade Católica do Paraná. Disponível em: <http://dominiopublico.mec.gov.br/download/teste/arqs/cp008701.pdf>. Acesso em 25.03.2015.

${ }^{10}$ SANTOS, Theophilo de Azeredo. Op. cit., pp. 31-32 apud PAULS, Manfred, idem.

${ }^{11}$ GONÇALVES, Carlos Roberto. Op. Cit., p. 217.

12 Para uma análise mais aprofundada do tema, veja-se: RODAS, João Grandino. Sociedade Comercial e Estado. São Paulo: Saraiva, 1995, pp. 23-27.

13 GONÇALVES, Carlos Roberto. Op. Cit., pp. 218-219.
} 
As teorias da realidade ganharam amplo espaço no cenário jurídico, em detrimento da anterior concepção ficcionista. Inobstante não sejam isentas de críticas, as teorias realistas ofereceram um importante suporte para explicar o fenômeno de um grupo coletivo, unido por objetivos comuns de seus integrantes, que adquire personalidade própria, devidamente reconhecida pelo Estado e distinta de cada um de seus membros.

Com o natural decurso do tempo e aprimoramento das ideias, advieram as doutrinas contemporâneas, que buscaram perquirir a natureza da pessoa jurídica com um foco diverso das clássicas. Nas palavras de João Grandino Rodas:

\begin{abstract}
As teorias ditas clássicas, embora variegadas, coincidiram em um ponto: buscavam o substrato sociológico, a essência ontológica do que em direito se denomina pessoa jurídica. Já as doutrinas contemporâneas, cansadas do dogmatismo das teorias clássicas, vêem a questão sob o novo prisma, mormente porque os instrumentos jurídicos tradicionais não aptos a enfrentar a conformação atual da pessoa jurídica. São características das doutrinas contemporâneas: o abandono da ultrapassada concepção unitária e absoluta da personalidade, a não-aceitação de construções apriorísticas e gerais, e a consideração da personalidade jurídica como meio técnicojurídico de se alcançar certos objetivos. [...] A progressiva conscientização da relatividade e historicidade da pessoa jurídica veio pari passu com a diminuição do interesse dos estudiosos do direito no que tange à conceituação à maneira tradicional da pessoa jurídica. ${ }^{14}$
\end{abstract}

\title{
3. CONCEITOS DE EMPRESA E SOCIEDADE EMPRESÁRIA
}

O conceito de empresa pode ser analisado sob perfis diversos, cada um deles gerando diferentes significados. Conforme Rubens Requião, os juristas não lograram êxito em edificar um conceito jurídico de empresa, isto é, sem que tivessem que recorrer à Economia:

Em vão, os juristas têm procurado construir um conceito jurídico para tal organização. Sente-se em suas lições certo constrangimento, uma verdadeira frustração por não lhes haver sido possível compor um conceito jurídico próprio de empresa, tendo comercialista que se valer do conceito formulado pelos economistas. $^{15}$

O jurista italiano Alberto Asquini entendeu a empresa como um fenômeno poliédrico, possuindo, portanto, quatro perfis: a) subjetivo, que vê a empresa como o empresário, o sujeito que organiza e desenvolve a atividade econômica; b) racional ou funcional, onde a empresa assume a feição de atividade empreendedora, isto é, é um instrumento dessa atividade; c) patrimonial ou objetivo, segundo o qual a empresa é o estabelecimento, isto é, o complexo de bens corpóreos e incorpóreos organizados pelo empresário para

\footnotetext{
${ }^{14}$ RODAS, João Grandino. Ibidem, pp. 26-27.

${ }^{15}$ REQUIÃO, Rubens. Curso de Direito Comercial. Vol. 1, 26. ed. São Paulo: Saraiva, 2005, p. 40.
} 
desenvolvimento da atividade empresarial; e d) o perfil corporativo, onde a empresa é uma instituição ${ }^{16}$.

A Constituição Federal brasileira de 1988, em seu art. 1º, IV, dispõe que a República Federativa do Brasil tem como fundamento os valores sociais do trabalho e da livre iniciativa. Já em seu art. 170, caput, prevê que a ordem econômica será fundada na valorização do trabalho humano e na livre iniciativa. A união de ambos os dispositivos demonstra que o constituinte originário, embora não se refira à empresa, ao destacar o trabalho e a livre iniciativa como importantes valores da ordem econômica, teve por intuito entender a empresa como instrumento da atividade empreendedora e que ela é em si um valor social. Desse modo, por ilação, pode-se sustentar que a Carta Magna adotou o perfil funcional de empresa.

Esta linha de raciocínio considera a empresa "toda organização destinada à produção e comercialização de bens e serviços para um mercado"17, sendo "exercida profissionalmente pelo empresário, através do estabelecimento" ${ }^{18}$. Mesmo antes da Lei fundamental, o texto do art. $1^{\circ}$, parágrafo único, do Decreto-lei $n^{\circ} 7.666 / 45$ já considerava que o vocábulo empresa abrangia "as pessoas físicas ou jurídicas de natureza comercial ou civil que disponham de organização destinada à exploração de qualquer atividade com fins lucrativos"19.

A consolidação da teoria da empresa se deu com o Código Civil de 2002, que, “seguindo a concepção do italiano de 1942, abandona a noção de comerciante para adotar a de empresário" ${ }^{20}$. A atual codificação não conceituou a atividade empresária em si, porém, em seu art. 966, considerou o empresário como sendo aquele "quem exerce profissionalmente atividade econômica organizada para a produção ou a circulação de bens ou de serviços". Portanto, extrai-se o conceito de empresa a partir do empresário.

A empresa pode ser exercida por uma pessoa física ou jurídica, ressaltando-se que, antes do início da atividade, devem o empresário e a sociedade inscrever-se no Registro Público de Empresas Mercantis ${ }^{21}$. O registro, via de regra, possui natureza declaratória ${ }^{22}$; assim, caso não haja, não haverá impedimento para a configuração da empresa, porém o

\footnotetext{
${ }^{16}$ REQUIÃO, Rubens, ibidem, p. 44.

17 SILVA, Américo Luís Martins da. A ordem constitucional econômica. Rio de Janeiro: Lumen Juris, 1996, p. 81 apud NAPOLITANO, Carlo José. A Nacionalidade das Sociedades Empresariais. Disponível em:< http://www.aedb.br/seget/arquivos/artigos08/114_A_NACIONALIDADE_DAS_SOCIEDADES_ EMPRESARIAIS.pdf > . Acesso em 07.04.2015.

${ }^{18}$ BULGARELLI, Waldirio. Sociedades comerciais. 10. ed. São Paulo: Atlas, 2001, p. 294.

19 Semelhante disposição esteve posteriormente prevista no art. $6^{\circ}$, da lei $\mathrm{n}^{\circ}$ 4.137/62: "Considera-se empresa toda organização de natureza civil ou mercantil destinada à exploração por pessoa física ou jurídica de qualquer atividade com fins lucrativos".

${ }^{20}$ SZTAJN, Raquel. Teoria Jurídica da Empresa: Atividade Empresária e Mercados. 2. ed. São Paulo: Atlas, 2010, p.82.

${ }^{21}$ SZTAJN, Raquel. Idem.

${ }^{22}$ No caso do empresário rural, o registro possui natureza constitutiva. Vide nota 17.
} 
empresário ficará em situação irregular, o que pode lhe acarretar uma série de consequências legais, como a impossibilidade de receber o tratamento favorecido de microempresa.

Acerca da distinção entre empresa e sociedade, ensina Rubens Requião:

A principal distinção, e mais didática, entre empresa e sociedade comercial é a que vê na sociedade o sujeito de direito, e na empresa, mesmo com exercício da atividade, o objeto de direito. Com efeito, a sociedade comercial, desde que esteja constituída nos termos da lei, adquire categoria de pessoa jurídica. Torna-se capaz de direitos e obrigações. A sociedade comercial, assim, é empresário, jamais empresa. É a sociedade comercial, como empresário, que irá exercitar a atividade produtora. $^{23}$

Desse modo, em síntese, empresa é o objeto de direito, empresário é a pessoa física, e a sociedade empresária é a pessoa jurídica, sujeito de direito, que exerce a empresa. As noções apresentadas são importantes a compreensão do item 6 deste trabalho, pois as sociedades por ações são sempre empresárias (art. 982, parágrafo único, do Código Civil).

\section{O RECONHECIMENTO DA PERSONALIDADE JURÍDICA DA SOCIEDADE ESTRANGEIRA}

Antes de se analisar os critérios de atribuição de nacionalidade à sociedade, convém destacar que esta precisa a priori ter reconhecida sua personalidade pelos ordenamentos jurídicos dos Estados nos quais pretende atuar. Veja-se lição de Hee Moon Jo:

\footnotetext{
Qualquer pessoa jurídica tem o local de incorporação no qual adquire personalidade jurídica. Para que essa pessoa jurídica possa vir a atuar em outro país, deverá adquirir personalidade jurídica daquele país, ou então, ter sua personalidade reconhecida naquele país. ${ }^{24}$
}

O reconhecimento da personalidade da pessoa jurídica é situação diversa da concessão de autorização para seu funcionamento. No primeiro caso, acontece o reconhecimento formal do Estado da constituição de uma pessoa jurídica. Já no segundo, ocorre um ato prévio, necessário, do qual é dependente a pessoa jurídica para exercer suas atividades no território de um determinado Estado. Essa pessoa jurídica, autorizada a funcionar em outro Estado que não o da sua constituição, passa a possuir, nos dizeres de Maria Helena Diniz, "capacidade funcional"25. Em razão disso, a natureza da autorização é constitutiva.

Segundo Eduardo Espínola, didaticamente, pode-se dividir o reconhecimento da pessoa jurídica estrangeira em dois sistemas: o dos países que seguem a teoria da ficção (sistema atributivo) e o dos que seguem a teoria da realidade da pessoa jurídica (sistema

${ }^{23}$ REQUIÃO, Rubens. Op. cit., p. 49.

${ }^{24}$ JO, Hee Moon. Moderno Direito Internacional Privado. São Paulo: LTR, 2001, p. $416 .{ }^{25}$ DINIZ, Maria Helena. Lei de Introdução ao Código Civil Brasileiro Interpretada. 6. ed. atualiz. São Paulo: Saraiva, 2000, p. 32. 
declaratório). O primeiro sistema exige a autorização do Estado como medida necessária para o reconhecimento da pessoa jurídica privada estrangeira, enquanto que o segundo prega pelo reconhecimento de pleno direito ${ }^{26}$. Salienta o autor que a tendência mundial está no sentido do reconhecimento independentemente de qualquer autorização ${ }^{27}$, o que não poderia ser diferente em razão do hodierno cenário globalizado.

No Brasil, a primeira Lei de Introdução ao Código Civil (LICC - Lei no 3.071/16) dispunha, em seu art. 19, que: "Serão reconhecidas as pessoas jurídicas estrangeiras". Como se vê, optou o legislador da época por adotar o sistema declaratório. Contudo, com o advento da segunda LICC (Decreto-lei $\left.\mathrm{n}^{\mathrm{o}} 4.657 / 42\right)^{28}$, a mencionada disposição não mais compôs o texto legal.

Segundo posicionamento de Theophilo Azeredo Santos, o vetusto artigo 19 permanece implicitamente vigente no ordenamento, em respeito ao princípio da continuidade das leis, positivado pelo artigo $2^{\circ}$ da lei atual, já que não houve qualquer revogação tácita ou expressa $^{29}$. Ademais, sua prescrição se harmoniza perfeitamente com os artigos 11 e 17 da recente norma. Interpretação diversa, porém de efeitos semelhantes, a qual nos filiamos, é a no sentido de que, inobstante o antigo art. 19 não esteja mais em vigor, uma interpretação teleológica da nova lei demonstra a nítida opção do legislador brasileiro pelo reconhecimento da pessoa jurídica estrangeira. Desse modo, prima facie, o novel diploma adota o sistema declaratório.

Saliente-se, no entanto, que, após a segunda LICC, o direito brasileiro não mais reconhece um único sistema. Isto porque, nos termos do art. $11, \S 1^{\circ}$, da norma em comento, as pessoas jurídicas estrangeiras não poderão ter no Brasil "filiais, agências ou estabelecimentos antes de serem os atos constitutivos aprovados pelo Governo brasileiro". Essa exigência demonstra que o legislador também desejou adotar o sistema atributivo.

Assim, caso uma sociedade estrangeira, verbi gratia, opte por celebrar um contrato com uma sociedade brasileira, basta que aquela esteja regularmente constituída que sua personalidade será reconhecida de pleno direito independentemente de qualquer autorização (sistema declaratório). Todavia, se optar por constituir "filial, agência ou estabelecimento" em

\footnotetext{
${ }^{26}$ ESPINOLA, Eduardo; ESPINOLA FILHO, Eduardo. Lei de Introdução ao Código Civil Brasileiro. v. 3, 2. ed, atualizada por José da Silva Pacheco. Rio de Janeiro: Renovar, 1995, pp. 141-142.

${ }^{27}$ ESPINOLA, Eduardo; ESPINOLA FILHO, Eduardo. Idem.

${ }^{28}$ Cumpre destacar a segunda LICC sofreu uma alteração quanto ao nomen juris. Nos termos do art. $2^{\circ}$ da Lei $n^{\circ}$ 12.376/2010, o diploma em comento passou a ser nomeado de Lei de Introdução às normas do Direito Brasileiro (LINDB).

${ }^{29}$ SANTOS, Theophilo de Azeredo. Op. cit. apud PAULS, Manfred. Ibidem, p. 34.
} 
território brasileiro, a situação se modificará. Deverá, nesse caso, solicitar autorização prévia ao Governo brasileiro (sistema atributivo).

A segunda LICC (ou LINDB) será analisada com maiores detalhes oportunamente. Por ora, é importante acentuar que, independente de qual corrente se adote, ambas afirmam que o ordenamento brasileiro reconhece a personalidade jurídica das sociedades estrangeiras, adotando hibridamente o sistema declaratório e atributivo.

\title{
5. Conceito de nacionalidade e os principais critérios adotados para atribuição de nacionalidade às sociedades
}

Nos dizeres de Alexandre de Moraes, nacionalidade é:

\begin{abstract}
o vínculo jurídico político que liga um indivíduo a um certo e determinado Estado, fazendo deste indivíduo um componente do povo, da dimensão pessoal deste Estado, capacitando-o a exigir sua proteção e sujeitando-o ao cumprimento de deveres impostos $^{30}$
\end{abstract}

Como se verifica no conceito acima, a nacionalidade é um vínculo do indivíduo, pessoa física, com o Estado. Desse modo, em razão de ser um instituto originalmente limitado aos indivíduos, longas e intermináveis discussões se travaram na doutrina acerca da questão se seria possível às pessoas jurídicas possuir uma nacionalidade.

$\mathrm{Na}$ falta de outra denominação mais adequada, a expressão "nacionalidade das sociedades" acabou por obter ampla consagração ${ }^{31}$, sendo mencionada em diversos compêndios, leis, tratados e convenções internacionais ${ }^{32}$. Atualmente, não há grandes obstáculos em se conferir nacionalidade às sociedades. A ressalva que deve ser feita é no sentido de que a extensão do conceito de nacionalidade dos indivíduos para além de sua fronteira não importa na igual extensão de todos os efeitos dela decorrentes.

Veja-se, por exemplo, a seguinte situação: a nacionalidade, dentre seus efeitos, faculta ao indivíduo o desempenho de funções políticas e lhe determina obrigações militares. Seria no mínimo estranho pretender estender às sociedades o dever de alistamento militar e a faculdade de se eleger a um cargo político. O instituto deve ser adaptado à realidade das pessoas jurídicas. Saliente-se, no entanto, que há juristas que defendem ser a pessoa física a única

\footnotetext{
${ }^{30}$ MORAES, Alexandre de. Direito constitucional. 26. ed. São Paulo: Atlas, 2010, p. 208.

31 TEIXEIRA, Egberto Lacerda. A Nacionalidade e as Sociedades Comerciais no Brasil e no Estrangeiro, p. 27. In: Revista dos Tribunais n. ${ }^{\circ}$ 420, p. 20-37, São Paulo, 1970.

32 BATIFFOL, Henri. Droit International Privé. 4. ed., n. 192. Paris: L.G.D.J., 1967, pp. 221-222.
} 
suscetível de adquirir nacionalidade, com base no entendimento de que uma sociedade não seria mais do que um contrato entre as partes. ${ }^{33}$

Há de se ter em mente que, se a nacionalidade já possui certas problemáticas em relação aos indivíduos, em razão da diferença de critérios que variam de país para país (v.g., jus soli, jus sanguinis), a controvérsia, no âmbito das sociedades, acentua-se ainda mais. Com vistas a continuar a análise do assunto, mister que sejam apresentados os principais critérios que surgiram para atribuir determinada nacionalidade a uma sociedade.

O primeiro a ser analisado é o critério do local da constituição ou da “incorporação" 34 da sociedade. A nacionalidade a ser atribuída a uma sociedade será a do local onde foi constituída ou incorporada. Na visão dos países que seguem esse critério, já que foi a lei local que atribuiu personalidade jurídica à sociedade, nada mais lógico do que escolher a mesma lei para lhe conferir nacionalidade. Esse critério prevalece nos ordenamentos que predomina o liberalismo da vontade individual dos contratantes, como Estados Unidos e a Grã-Bretanha ${ }^{35}$.

Como exemplo de aplicação prática desse critério pela Grã-Bretanha, cita-se o caso Janson v. Driefontein Consolidated Mines, $l t d .{ }^{36}$. No final do século XIX, havia uma sociedade mineradora incorporada sob a lei de Transvaal ${ }^{37}$, que possuía como acionistas indivíduos residentes na Europa. A sociedade em comento optou por assegurar o ouro extraído das minas contra captura e apreensão enquanto estivesse sendo transportado de Transvaal para o Reino Unido. Em outubro de 1899, um carregamento de ouro foi apreendido pelo governo de Transvaal, pouco antes do estopim da guerra entre esses Estados.

O caso é extenso e foge ao objeto deste trabalho analisa-lo em detalhes, interessando destacar tão somente que a House of Lords considerou que a sociedade mineradora em questão possuía nacionalidade de Transvaal, uma vez que sua incorporação tinha se dado nesse Estado, sendo irrelevante, portanto, o fato de seus acionistas serem nacionais de países

\footnotetext{
${ }^{33}$ NIBOYET, Jean-Pierre. Traité de Droit International Privé Français. Paris: Recueil Sirey, 1950, p. 34.

34 O vocábulo "incorporação" é utilizado no direito brasileiro para se referir à operação pela qual uma ou mais sociedades são absorvidas por outras, que lhes sucede em todos os direitos e obrigações, conforme dispõe o art. 227 da Lei $n^{\circ}$ 6.404/76. Não é esse o sentido utilizado nesse trabalho. O termo incorporação aqui é uma mera tradução de incorporation, que se aproxima à ideia de local de constituição da sociedade. Optou-se por sua utilização em razão de ser vastamente encontrado na doutrina sobre o tema.

35 TEIXEIRA, Egberto Lacerda. Op. cit., pp. 27-28.

${ }^{36}$ Janson v. Driefontein Consolidated Mines, ltd., (1902) AC 484. In: MICHEL, Keith. War, terror and carriage by sea. London: LLP, 2004, pp. 14-17.

37 Transvaal designava originalmente territórios que se constituíram em uma república boer, no norte da África do Sul. Em 1902, essa região foi anexada pelos ingleses, vindo a se tornar uma das quatro províncias sulafricanas em 1910.
} 
europeus. Esse posicionamento levou a Corte a considerar a sociedade como inimiga quando estourou a guerra entre Transvaal e o Reino Unido. ${ }^{38}$

O principal inconveniente desse sistema seria a possibilidade de fraude, uma vez que é permitida às partes a escolha abusiva do local de constituição. Ademais, surgem dúvidas acerca de qual seria o momento exato em que se deu a constituição da sociedade (assinatura do instrumento pelas partes, registro do instrumento, dentre outros) e a obtenção da personalidade jurídica.

Outro sistema utilizado é o critério da sede social estatutária. Esse critério não diverge muito do apresentado anteriormente. A nacionalidade será determinada pela sede estatutária, eleita e indicada pelas partes no contrato social ou estatuto. Esse critério teve certo ressurgimento no Mercado Comum Europeu, em razão do art. 58 do Tratado de Roma ${ }^{39}$. Por ser semelhante ao acima indicado, igualmente está sujeito à fraude por escolha abusiva da sede social pelas partes. Isso porque poderia facilmente uma sociedade estipular sua sede em um país que possua uma legislação mais conveniente com os seus interesses, enquanto que a exploração de seus negócios e a fixação de seu centro administrativo ocorreria em outra nação.

Um terceiro sistema é o critério da sede social efetiva ou real. De acordo com ele, a nacionalidade da sociedade é determinada pela lei do local onde está situada a sede da sociedade. No entanto, esse critério diverge do anterior, pois aqui a sede tem que ser efetiva, real e não fictícia. O sistema é preferido por ordenamentos que defendem o caráter institucional, e não o meramente contratual, das sociedades. Segundo a doutrina, esse critério outorga maior segurança jurídica às relações. ${ }^{40}$

O critério da sede social efetiva teve ampla aplicação pela jurisprudência francesa. Como exemplo, cita-se o caso Demoiselle Peugeot c. Consorts Peugeot-Friedel ${ }^{41}$, julgado pela Câmara Civil da Corte de Cassação Francesa, em 17 de junho de 1958. Com o objetivo que seus bens fossem melhor geridos, Robert Peugeot os confiou à sociedade fiduciária Poseidon, que era uma sociedade anônima constituída segundo as leis da Suíça e com sede social nesse país. Os acionistas da Poseidon eram simultaneamente seus diretores, o que, segundo a lei suíça, não gerava problema algum. A lei francesa, por sua vez, caracterizava 38 LAUTERPACHT, Elihu; GREENWOOD, Christopher; LEE, Karen (editors). International Law Reports: Annual Digest and Reports of Public International Law Cases 1941-1942, vol. 10. Reino Unido: Cambridge University Press, 1994, p. 556.

39 TEIXEIRA, Egberto Lacerda. Op. cit., p. 28.

${ }^{40}$ Ibidem.

${ }^{41}$ FRANCE, Cour de Cassation, Ch. Civ., 1re. Sect., 17 juin 1958 [2 arrêts]). In: RODAS, João Grandino. Op. Cit., pp. 271-272. 
essa situação como simulação. No entanto, a jurisprudência francesa entendia que a aplicação de uma lei estrangeira, que dispusesse em contrário à sua norma em um eventual litígio, não ofenderia a ordem pública francesa.

Após o falecimento do senhor Peugeot, seus herdeiros obtiveram a confirmação de seus direitos sobre as ações da Poseidon em um julgamento proferido pelo Tribunal da Basiléia. Irresignada em decorrência de um desentendimento posterior, senhora Peugeot ajuizou demanda perante um tribunal francês, pleiteando a nulidade da sociedade Poseidon, invocando como argumentos a ilicitude e a simulação, com fulcro na lei francesa. O problema foi solucionado pela Câmara Civil, que reconheceu a existência legal da sociedade Poseidon na França, porém se posicionou no sentido de que tudo que dissesse respeito à sua constituição, modificação e dissolução seria regido pela lei suíça, que era a lei tanto de sua constituição como de sua sede social. Afastou-se, portanto, a qualificação francesa de simulação do caso. ${ }^{42}$

Além da França, o critério da sede social efetiva também encontra adeptos em países como a Itália, Alemanha e Bélgica ${ }^{43}$. Há de se ter em mente que o conceito de sede social não pode ser confundido com os centros de exploração mantidos pela sociedade. A sede social é única, enquanto que os centros de exploração podem ser vários. A sede social efetiva é onde se situam os órgãos que verdadeiramente dirigem a sociedade. Desse modo, em situações que as legislações nacionais permitem a realização de reuniões da diretoria e das assembleis em locais diversos da sede social, sugere a doutrina que se recorra ao critério do local onde estão situados os órgãos centrais de direção e comando da sociedade para determinar a sede social efetiva ou real. ${ }^{44}$

Como se verifica, a eleição desse sistema impede que os sócios fraudem a lei com a escolha de uma sede que apenas seja conveniente aos seus interesses, puramente fictícia, bem como verifica um elo mais efetivo entre a sociedade e o Estado cuja lei será aplicada. No entanto, possui como inconveniente certa insegurança jurídica. Basta imaginar uma situação onde uma determinada sociedade, com sede jurídica em um Estado, se torne parte em um litígio e, no decorrer do regular trâmite processual, acabe por alterar sua sede social para outro Estado, por razões econômicas e estratégicas, sem que a lide tenha chegado ao fim ${ }^{45}$. Isto seria um claro expediente para alterar sua nacionalidade.

\footnotetext{
${ }^{42}$ RODAS, João Grandino. Op. Cit., p. 272.

${ }^{43}$ PAULS, Manfred, Op. cit., p. 52.

44 TEIXEIRA, Egberto Lacerda. Op. cit., p. 28.

45 PAULS, Manfred, Op. cit., p. 53.
} 
Há um quarto sistema que pode ser considerado um critério eclético de coincidência do local da constituição e da sede social. Com o escopo de minimizar os inconvenientes acima elencados, esse critério misto busca conjugar elementos de ambas as teorias, a fim de que se chegue a uma solução que promova maior segurança e certeza ao estatuto jurídico da pessoa jurídica. ${ }^{46}$

Por fim, o último sistema a ser destacado é o critério do controle através da nacionalidade dos sócios ou dos dirigentes. Esse critério é mais utilizado em períodos de guerra, quando se busca mais fortemente a defesa dos interesses dos Estados beligerantes aos quais pertencem sociedades cuja atuação, dirigida pelo inimigo, poderia danificá-los consideravelmente. Essa teoria possui como interesse prático a possibilidade de sequestrar e confiscar os bens dos súditos inimigos, interromper todo o tráfego ou direito de acesso aos tribunais, dentre outras medidas. ${ }^{47}$

De acordo com esse critério, a nacionalidade das pessoas jurídicas é

determinada pela nacionalidade dos seus sócios (capitais) ou dos seus dirigentes.
Para chegar a essa conclusão, os defensores da teoria do controle têm que proceder à
dissociação entre o estatuto jurídico ("statut juridique") que serve como
determinador normal das relações de direito internacional privado e a aligiância ou
subordinação política ("allégeance politique" ou "jouissance de droits") 48

A principal problemática que surge com a aplicação desse critério é uma latente insegurança jurídica. Isso porque uma determinada sociedade, mesmo sem ter qualquer tipo de alteração em sua sede social, estatutária ou efetiva, local de constituição ou centro de exploração, poderia ter sua nacionalidade alterada diversas vezes ao longo de um curto período. Ademais, exigiria do juiz uma análise tão cuidadosa do controle acionário ou administrativo no momento em que fosse julgar um eventual litígio que praticamente inviabilizaria sua atividade.

Apresentados os principais critérios atribuidores de nacionalidade às sociedades, percebe-se que nenhum deles por si só é capaz de atender a todas as exigências econômicas, políticas e jurídicas dos Estados, uma vez que apresentam certos inconvenientes.

\section{A nacionalidade da sociedade no ordenamento brasileiro}

\footnotetext{
46 TEIXEIRA, Egberto Lacerda. Op. cit., p. 28.

${ }^{47}$ PAULS, Manfred, Op. cit., p. 58.

48 TEIXEIRA, Egberto Lacerda. Op. cit. , pp. 28-29.
} 
A primeira LICC (Lei $\mathrm{n}^{\circ}$ 3.071/16) determinava em seu artigo 21 que "a lei nacional das pessoas jurídicas determina-lhe a capacidade", sem esclarecer qual seria o critério utilizado para determinar a nacionalidade da pessoa jurídica. A segunda LICC (Decreto-lei no 4.657/42), deu maior atenção ao assunto, dispondo, em seu art. 11, que "as organizações destinadas a fins de interesse coletivo, como as sociedades e as fundações, obedecem à lei do Estado em que se constituírem".

Serão analisados oportunamente alguns elementos adicionais desse dispositivo da segunda LICC, quando se tratar do tema da lei aplicável às sociedades. Nesse momento, é importante apenas fazer duas considerações. Primeiramente, que o vocábulo "sociedade", empregado pela lei em questão, era baseado no conceito trazido pelo Código Civil de 1916. Tal diploma, em seu art. 16, considerava que eram pessoas jurídicas de direito privado as "sociedades civis, religiosas, pias, morais, científicas ou literárias, as associações de utilidade pública e as fundações" (inciso I) e as "sociedades mercantis" (inciso II). Ademais, no art. 1.363, estipulava que celebravam contrato de sociedade as pessoas, que mutualmente se obrigavam a combinar seus esforços ou recursos, para lograr fins comuns. Portanto, o termo "sociedade", previsto na segunda LICC, englobava tanto as que possuíam fins econômicos quanto as que possuíam fins não econômicos. Em segundo lugar, que o critério adotado pelo art. 11 da segunda LICC foi o do local de constituição ou da incorporação.

A antiga Lei das Sociedades por Ações (Decreto-lei no 2.627/40), no entanto, previa, em seu art. 60, que "são nacionais as sociedades organizadas na conformidade da lei brasileira e que tem no país a sede de sua administração". Verifica-se a utilização de um sistema híbrido, conjugando-se elementos do critério da constituição da sociedade com o critério da sede social efetiva. Desse modo, surgiu um conflito entre disposições legais, o que levou a cogitação inicial de que segunda LICC havia revogado o Decreto-lei $n^{\circ}$ 2.627/40. Todavia, essa visão não prevaleceu. Jacob Dolinger assevera que:

(a) melhor conciliação dos dois textos é a exposta por Serpa Lopes, Miranda
Valverde e Cunha Peixoto, no sentido de que a lei de Introdução cuida de um
problema de natureza internacional, dando a solução à hipótese em que se configure
dúvida sobre a nacionalidade de uma pessoa jurídica, com laços em mais de um país,
optando pelo critério do país da constituição da sociedade. Já a lei de sociedades
anônimas cuida exclusivamente do critério para a conceituação da empresa [sic]
brasileira, e nisto nosso legislador foi mais exigente, condicionando-a à constituição
e à sede social no Brasil. 49

49 DOLINGER, Jacob. A Sociedade Anônima Brasileira - Critério determinador de sua Nacionalidade. In:

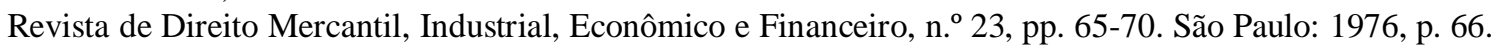


Sendo assim, predominou o entendimento de que as sociedades por ações se sujeitavam aos critérios do Decreto-lei $\mathrm{n}^{\circ}$ 2.627/40 (constituição e sede social efetiva) enquanto que as demais se submetiam à segunda LICC (apenas constituição).

Em 15.12.1976, adveio a atual Lei das Sociedades por Ações (Lei n 6.404/76), que revogou a anterior, excetuando, contudo, os artigos 59 a $73^{50}$. Sem embargo, a norma em comento também trouxe um critério complementar. Nos termos do art. 265, a legislação exige que a sociedade controladora do "Grupo de Sociedades" seja brasileira. Já em seu art. 269, VII, prescreve que a convenção deve conter "a declaração da nacionalidade do controle do grupo". Por fim, no parágrafo único do mesmo dispositivo, estabelece que:
Art. 269. [...]
Parágrafo único. Para os efeitos do número VII, o grupo de sociedades considera-se sob controle brasileiro se a sua sociedade de comando está sob o controle de:
a) pessoas naturais residentes ou domiciliadas no Brasil;
b) pessoas jurídicas de direito público interno; ou
c) sociedade ou sociedades brasileiras que, direta ou indiretamente, estejam sob o controle das pessoas referidas nas alíneas a e b.

Percebe-se, portanto, a coexistência de dois critérios sobre a conceituação de sociedade anônima brasileira: um genérico, previsto no art. 60 da antiga lei, que permanece em vigor e conjuga os elementos constituição e sede social, e um específico para os grupos de sociedades, previsto no art. 269 da atual lei, que também utiliza o elemento controle de pessoas naturais domiciliadas no Brasil ou de pessoas jurídicas de direito público interno.

É oportuno ainda destacar algumas disposições do Código Brasileiro de Aeronáutica (CBA - Lei $n^{\circ}$ 7.565/86). Seu art. 180 estipula que a exploração de serviços de transporte aéreo regular depende de concessão, enquanto que o de transporte aéreo não regular ou de serviços especializados, de autorização. Adiante, conforme o art. 181 e seus incisos, prevê que a concessão só será dada à pessoa jurídica brasileira se ela tiver: sede no Brasil; mínimo 4/5 (quatro quintos) de capital votante pertencente a brasileiros; e direção confiada exclusivamente a brasileiros. Já no que se refere à autorização, o art. 182 a outorga às sociedades anônimas que respeitem as condições do art. 181 ou às demais sociedades que possuam sede no Brasil e observem a maioria de sócios, o controle e direção de brasileiros.

Saliente-se que as disposições do CBA não versam sobre condições e critérios necessários para que uma sociedade ostente a nacionalidade brasileira, mas estipulam exigências adicionais para que ela possa exercer atividades as quais o legislador entende como mais sensíveis à segurança nacional. Trata-se, portanto, de uma tentativa de evitar a indevida 
interferência do capital estrangeiro nesses assuntos, a fim de uma maior preservação dos interesses brasileiros. Para lograr êxito nesse intento, nota-se novamente a utilização eclética de critérios pela legislação, inclusive o do controle.

Em 05.10.1988, com a promulgação da atual Constituição Federal, surgiram novas disposições. O seu art. 171, revogado pela Emenda Constitucional ${ }^{\circ}$ 6/95, estipulava que:

\title{
Art. 171. São consideradas:
}

I - empresa [sic] brasileira a constituída sob as leis brasileiras e que tenham sua sede e administração no País;

II - empresa [sic] brasileira de capital nacional aquela cujo controle esteja em caráter permanente sob a titularidade direta e indireta de pessoas físicas domiciliadas e residentes no País ou entidades de direito público interno, entendendo-se por controle efetivo da empresa [sic] a titularidade da maioria de seu capital votante e o exercício, de fato e de direito, do poder decisório para gerir suas atividades.

Observa-se que o constituinte originário se valeu do sistema já utilizado pela legislação das sociedades por açóes, isto é, a cumulação dos critérios da constituição com o a sede social efetiva em seu inciso I para conceituar "empresa brasileira" [sic] e o critério do controle no inciso II para conceituar "empresa brasileira de capital nacional" [sic], concedendo certos benefícios a essas últimas sociedades ${ }^{51}$. A doutrina da época assim se manifestava acerca das modificações trazidas pela novel Constituição:

\begin{abstract}
Em verdade, antes, a subdivisão da sociedade ou empresa [sic] brasileira era apenas doutrinária; agora, é legislativa, também. Em outras palavras, antes, a sociedade dita multinacional existia tão-somente de fato, eis que, muito embora fosse, na prática, universal e pacificamente considerada estrangeira, era, em teoria, considerada tão brasileira quanto às demais. Agora, a multinacional existe de fato e de direito, sendo uma empresa [sic] brasileira com restrições, ou uma empresa [sic] menos brasileira que as demais. ${ }^{52}$
\end{abstract}

\section{Conforme salienta Luís Roberto Barroso:}

(A) década de 90, no Brasil, foi o cenário de um conjunto amplo de transformações econômicas que mudaram o perfil do Estado brasileiro. [...] A Emenda Constitucional $\mathrm{n}^{\circ}$ 6, de 15 de agosto de 1995, suprimiu o art. 171 da Constituição, que trazia a conceituação de empresa brasileira de capital nacional e admitia a outorga a elas de proteção, benefícios especiais e preferências. ${ }^{53}$

A EC nº 06, além de revogar o art. 171, alterou a redação do inciso IX do art. 170, prevendo "tratamento favorecido para as empresas de pequeno porte constituídas sob as leis brasileiras e que tenham sua sede e administração no País”. No entanto, a lacuna criada com a revogação do dispositivo não teve o condão de afastar a opção do constituinte originário pelos

\footnotetext{
${ }^{51}$ Saliente-se que este critério estava previsto na Lei $\mathrm{n}^{\mathrm{0}} 7.232 / 84$, que versava sobre benefícios para sociedades de capital nacional.

52 CRISTIANO, Romano. A Nacionalidade da Empresa e a Nova Constituição Federal. In: Revista dos

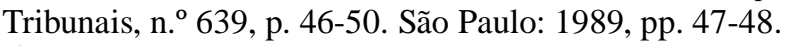

${ }^{53}$ CARMEN, Tiburcio; BARROSO, Luís Roberto. Direito Constitucional Internacional. Rio de Janeiro: Renovar, 2013, p. 562.
} 
critérios da constituição cumulada com a sede social efetiva, mas tão somente extinguiu determinadas restrições ao capital estrangeiro. Veja-se como posiciona a doutrina:

\begin{abstract}
Ora, a Carta Magna continua a determinar o que vem a ser uma empresa [sic] nacional, se não explicitamente, ao menos de forma indireta; aliada à vontade implícita do texto original, propicia uma boa margem de interpretação neste sentido, ou seja, pode-se concluir que para ser considerada brasileira a pessoa coletiva que atua em nosso país deve estar organizada juridicamente sob o império da lei brasileira e ter sua sede social efetiva instalada em solo pátrio; mesmo que tal conclusão não se encontre literalmente [...] no texto constitucional. ${ }^{54}$
\end{abstract}

Como exemplo a doutrina cita o art. $176, \S 1^{\circ}$, que dispõe que a pesquisa e lavra de recursos minerais somente poderão ser autorizadas a "brasileiros ou empresa [sic] constituída sob as leis brasileiras e que tenha sua sede e administração no País". 55

Cabe destacar, ainda, as restrições contidas no art. 222 da Constituição. O dispositivo versa sobre a propriedade jornalística e de radiodifusão sonora e de sons e imagens, exigindo que seja privativa de brasileiros natos ou naturalizados há mais de dez anos ou de pessoas jurídicas constituídas segundo as leis brasileiras e que tenham sede no país. O parágrafo $1^{\circ}$ impõe ainda que pelo menos $70 \%$ do capital total e do capital votante dessas sociedades pertença, direta ou indiretamente, a brasileiros natos ou naturalizados há mais de dez anos, que exercerão obrigatoriamente a gestão das atividades e estabelecerão o conteúdo da programação. Semelhante ao CBA, o art. 222 da Constituição não trata sobre os critérios de nacionalidade da sociedade, mas cuida de exigências adicionais para o exercício de atividade.

No que se refere ao atual Código Civil (Lei no 10.406/02), optou o legislador por se basear na redação dos dispositivos preservados do Decreto-lei $n^{\circ} 2.627 / 40$. Desse modo, o diploma adotou igualmente os critérios da constituição e o da sede social efetiva. Veja-se o que estipula o art. 1.126, in verbis:

Art. 1.126. É nacional a sociedade organizada de conformidade com a lei brasileira e que tenha no País a sede de sua administração.

Parágrafo único. Quando a lei exigir que todos ou alguns sócios sejam brasileiros, as ações da sociedade anônima revestirão, no silêncio da lei, a forma nominativa. Qualquer que seja o tipo da sociedade, na sua sede ficará arquivada cópia autêntica do documento comprobatório da nacionalidade dos sócios.

Percebe-se a profunda semelhança entre o dispositivo transcrito e o art. 60 do Decretolei $\mathrm{n}^{\circ}$ 2.627/40. A mesma situação ocorre com outros dispositivos do Código Civil:

\begin{tabular}{|c|c|}
\hline Código Civil de 2002 & Decreto-lei n' 2.627/40 \\
\hline $\begin{array}{l}\text { Art. 1.127. Não haverá mudança de nacionalidade } \\
\text { de sociedade brasileira sem o consentimento } \\
\text { unânime dos sócios ou acionistas. }\end{array}$ & $\begin{array}{l}\text { Art. 72. A sociedade anônima ou companhia brasileira } \\
\text { somente poderá mudar de nacionalidade mediante o } \\
\text { consentimento unânime dos acionistas. }\end{array}$ \\
\hline
\end{tabular}

\footnotetext{
${ }^{54}$ PAULS, Manfred, Op. cit., p. 76.

55 tctem, pp. 76-77.
} 


\begin{tabular}{|l|l|}
\hline $\begin{array}{l}\text { Art. 1.137. A sociedade estrangeira autorizada a } \\
\text { funcionar ficará sujeita às leis e aos tribunais } \\
\text { brasileiros, quanto aos atos ou operações praticados } \\
\text { no Brasil. }\end{array}$ & $\begin{array}{l}\text { Art. 68. As sociedades anônimas estrangeiras } \\
\text { autorizadas a funcionar ficarão sujeitas às leis e aos } \\
\text { tribunais brasileiros quanto aos atos ou operações que } \\
\text { praticarem no Brasil. }\end{array}$ \\
\hline $\begin{array}{l}\text { Art. 1.141. Mediante autorização do Poder } \\
\begin{array}{l}\text { Executivo, a sociedade estrangeira admitida a a } \\
\text { funcionar no País pode nacionalizar-se, transferindo } \\
\text { sua sede para o Brasil. }\end{array}\end{array}$ & $\begin{array}{l}\text { Art. 71. A sociedade anônima estrangeira, autorizada a } \\
\text { funcionar no país, pode, mediante autorização do } \\
\text { Governo Federal, nacionalizar-se, transferindo sua sede } \\
\text { para o Brasil. }\end{array}$ \\
\hline
\end{tabular}

Ao longo do debate acerca do Projeto de Código Civil (Projeto de Lei $n^{\circ}$ 634/75), foi proposta a Emenda $n^{\circ} 119 / 84$, que incluía um terceiro inciso ao art. 1.126: "ter capital votante sob o controle de brasileiro ou de sociedade nacional”, porém a modificação não vingou. Assim, o CC/02 veio à luz sem utilizar-se do critério do controle. Como visto no quadro acima, o diploma, à semelhança da legislação anterior, faculta, em seu art. 1.127, a troca de nacionalidade pelo consentimento unânime dos sócios ou acionistas da sociedade e, em seu art. 1.141, possibilita a nacionalização da sociedade estrangeira, admitida a funcionar no país, mediante a transferência de sua sede para o Brasil, desde que autorizada pelo Poder Executivo.

Como já exposto, o Código Civil, ao reproduzir as normas do Decreto-lei no 2.627/40, acabou por torná-las aplicáveis também a outros tipos societários além da sociedade anônima. Nesse diapasão, leciona Leonardo Régnier:

[O] Decreto de 1940, configurando a antiga Lei das Sociedades por Ações, disciplinava apenas esse tipo societário. E mesmo depois da Lei 6.404/76 (atual Lei das Sociedades por Ações), que manteve vigorando os artigos referentes à nacionalidade, as sociedades que lhe deviam atenção eram, a rigor, apenas aquelas por ações - ainda que se pudesse (e por vezes devesse) estender a aplicação às demais sociedades.

Ocorre que a partir do novo Código Civil fica ampliado o alcance das normas sobre nacionalidade, não se restringindo mais suas imposições às sociedades anônimas, mas sim, ao contrário, fazendo por alcançar todos os tipos societários - de agora em diante regulados pelo novo Estatuto civil. ${ }^{56}$

O mencionado autor faz uma ressalva no sentido de que essa ampliação já teria ocorrido com o art. 171 da Constituição Federal. Contudo, após sua revogação pela EC no 6/95, a disciplina voltou a ser regulada apenas pelo Decreto-lei $n^{\circ} 2.627 / 40$, nas disposições mantidas em vigor pelo art. 300 da Lei $\mathrm{n}^{\circ}$ 6.404/76. O CC/02, portanto, supriu a lacuna que subsistia até sua elaboração. O jurista realça, ademais, que não houve qualquer revogação expressa na lei, de modo que só seria possível sustentar a ocorrência de uma eventual revogação, sob o argumento de que ela teria sido tácita em decorrência de norma posterior sobre mesma matéria. Data venia, não se apoia os defensores dessa tese, haja vista que a lei

56 RÉGNIER, Leonardo Medeiros. Nacionalidade das sociedades comerciais. Curitiba: Juruá, 2002, pp. $230 / 231$. 
das sociedades por ações constitui lex specialis, aplicável apenas a esse tipo societário, não sendo derrogável por uma lei geral como o CC/02.

Por fim, merece destaque que o CC/02 restringiu o conceito de sociedade, passando a abranger apenas aquelas que possuem fins econômicos ${ }^{57}$. Desse modo, em atenção a uma leitura harmônica do ordenamento jurídico brasileiro, onde se lê "sociedade e as fundações", no art. 11, caput, da segunda LICC, deve-se ler "associações e as fundações", isto é, pessoas jurídicas privadas sem fins econômicos. Considerando-se que apenas as sociedades com fins econômicos estão atualmente sujeitas à disciplina prevista no CC/02 (critérios da constituição e sede social efetiva), aquelas que possuem fins não econômicos permanecem reguladas pela segunda LICC, atual LINDB.

\section{Os principais critérios adotados para escolha da lei aplicável às sociedades}

O estatuto jurídico da sociedade regula a natureza jurídica da sociedade, envolvendo, portanto, sua constituição, administração, dissolução, capacidade de fato e de direito, organização interna, emissão de títulos, dentre outras matérias. Feita essa breve enumeração, convém esclarecer que o tema da lei aplicável possui estreita relação com o da nacionalidade, a ponto de doutrina renomada sustentar que "a submissão de uma sociedade à lei de determinado país, a lex societatis, coincide com a nacionalidade da sociedade" ${ }^{~}$. Em razão disso, pode-se vislumbrar, basicamente, a utilização de dois critérios, que já foram analisados nos tópicos anteriores, adaptados agora ao conflito de leis: O critério da constituição (ou incorporação) da sociedade e o critério da sede social efetiva.

De acordo com o primeiro, será aplicável à sociedade a lei do local onde foi constituída, que disciplinará as normas de registro e publicidade, necessárias para lhe conferir capacidade e personalidade, bem como regerá o seu estatuto jurídico. Em contraponto, o critério da sede social efetiva advoga que será aplicada à sociedade a lei do local de sua administração real.

A principal crítica feita à teoria da incorporação é a mesma, isto é, enquanto promove maior segurança jurídica, essa teoria abre considerável margem para fraude, uma vez que permite a escolha abusiva do local de constituição pelos. Por outro lado, a crítica feita à teoria

\footnotetext{
${ }^{57}$ Art. 981, caput, do CC/02: "Celebram contrato de sociedade as pessoas que reciprocamente se obrigam a contribuir, com bens ou serviços, para o exercício de atividade econômica e a partilha, entre si, dos resultados". ${ }^{58}$ DOLINGER, Jacob. Direito Internacional privado: parte geral. 4. ed. atualiz. Rio de Janeiro: Renovar, 1997, p. 441.
} 
da sede social efetiva é que, mesmo dispondo de melhores ferramentas para coibir a fraude, gera certa insegurança jurídica.

Ressalte-se que outros critérios além desses dois principais podem ser utilizados pelos Estados e previstos em documentos convencionais. Como exemplo, cita-se o critério do centro dos negócios, que sustenta ser aplicável à sociedade a lei do lugar principal de seus negócios.

\subsection{A eleição da lei aplicável à sociedade no ordenamento brasileiro}

Conforme já analisado nesse trabalho, a segunda LICC, doravante LINDB $^{59}$, em seu art. 11, caput, adota o critério da incorporação. Analisando-a agora dentro do tema do conflito de leis, cabe abordar elementos adicionais desse dispositivo, previsto em seu parágrafo primeiro, in verbis:

Art. 11. As organizações destinadas a fins de interesse coletivo, como as sociedades e as fundações, obedecem à lei do Estado em que se constituírem.

$\S 1$ 을 Não poderão, entretanto ter no Brasil filiais, agências ou estabelecimentos antes de serem os atos constitutivos aprovados pelo Governo brasileiro, ficando sujeitas à lei brasileira.

Destaca-se, inicialmente, que as sociedades sujeitas à disciplina da norma em comento são apenas as estrangeiras. Isto porque, como exposto, apenas as associações e fundações brasileiras ainda são reguladas pela LINDB, haja vista que o critério de atribuição de nacionalidade às sociedades com fins econômicos é o do art.1.126 do CC/02.

A LINDB elege como lei aplicável a do local em que a sociedade foi constituída, o que leva à conclusão que o princípio da lei domiciliar foi preservado. Além disso, no parágrafo primeiro, o legislador exige uma autorização governamental, a fim de que uma determinada sociedade possa estabelecer "filiais, agências ou estabelecimentos" em território brasileiro (sistema atributivo).

A exigência tem por escopo impedir que uma sociedade se estabeleça no país com fins ilícitos, como, verbi gratia, o intuito de sonegar impostos. Tendo seus atos aprovados pelo governo brasileiro, após a devida análise pelos órgãos administrativos, as sociedades ficam, nos termos da LINDB, "sujeitas à lei brasileira" 60 .

\footnotetext{
59 Optou-se por nomeá-la segunda LICC no tópico 6, em razão de estar sendo feita uma análise histórica do ordenamento brasileiro. Como o presente tópico aborda o ordenamento contemporâneo, passou-se a empregar LINDB.

60 Semelhante disposição é encontrada no art. 1.137, caput, do CC/02: "A sociedade estrangeira autorizada a funcionar ficará sujeita às leis e aos tribunais brasileiros, quanto aos atos ou operações praticados no Brasil".
} 
Saliente-se que o Código de Processo Civil (Lei no 5.869/73) contribui com prescrição legal acerca do domicílio da pessoa jurídica. Inserido no capítulo da competência internacional, o art. 88 e seus incisos preveem as hipóteses de competência relativa ou concorrente da autoridade brasileira, dispondo, no parágrafo único, que "reputa-se domiciliada no Brasil a pessoa jurídica estrangeira que aqui tiver agência, filial ou sucursal". Semelhante disposição é encontrada no novo Código de Processo Civil (Lei $n^{\circ}$ 13.105/15). Agora inserido no capítulo dos limites da jurisdição nacional, o art. 21 e seus incisos tratam da competência concorrente, prevendo, no parágrafo único, que "considera-se domiciliada no Brasil a pessoa jurídica estrangeira que nele tiver agência, filial ou sucursal".

Portanto, de acordo com a LINDB, a sociedade possui duas escolhas: a) conservar-se no exterior e não estabelecer "filiais, agências ou estabelecimentos" no Brasil, de modo que permanecerá sob o império da lei do Estado de sua incorporação, o que não impedirá que negocie no Brasil ou mesmo recorra a Tribunais brasileiros (sistema declaratório) ${ }^{61}$; ou b) instalar-se em território brasileiro, após a devida autorização governamental (sistema atributivo), sujeitando-se, assim, à lei brasileira. É importante ressaltar que a sociedade, ao optar por se instalar no Brasil, não perde sua nacionalidade, mas tão somente atrai a aplicação da lei brasileira e, consequentemente, as restrições de ordem pública.

Sobre a parte que restou vigente da antiga Lei das Sociedades por Ações (Decreto-lei $n^{\circ} 2.627 / 40$ ), reitera-se o que já foi escrito em tópicos anteriores, cabendo trazer poucos elementos adicionais. Uma leitura de seu art. 60 leva à conclusão de que sociedades de nacionalidade brasileira são aquelas organizadas sob o império da lei brasileira. Logo, a contrario sensu, as sociedades estrangeiras serão aquelas organizadas segundo a lei de outros Estados $^{62}$.

Segundo o art. 66, as sociedades anônimas estrangeiras que funcionarem em território nacional terão a mesma denominação que possuem em seu país de origem, podendo, contudo, acrescentar as expressões "do Brasil” ou "para o Brasil”. Já o art. 68 segue a mesma linha que o art. 11 da LINDB, sujeitando à lei brasileira "sociedades anônimas estrangeiras autorizadas a funcionar" no Brasil, no que se refere aos atos ou operações que praticarem no território nacional.

\footnotetext{
${ }^{61}$ DINIZ, Maria Helena. Lei de Introdução ao Código Civil Brasileiro Interpretada. 6.ed. atualiz. São Paulo: Saraiva, 2000, pp. 296-300.

${ }^{62}$ FERREIRA, Lier Pires; BORGES, Marcos Aurélio dos Santos. Empresas estrangeiras e o direito ao desenvolvimento: uma análise jurídica da política de conteúdo local no setor petrolífero nacional. In: RIBEIRO, Marilda Rosado de Sá (Org.). Direito internacional dos investimentos. Rio de Janeiro, Renovar, 2014, pp. 477498.
} 
Portanto, em uma leitura sistêmica do ordenamento brasileiro, pode-se concluir que os atos ou operações praticadas no Brasil, por sociedade autorizada pelo governo brasileiro, se sujeitam à lei nacional, enquanto que o seu estatuto jurídico, "sua constituição ou forma de funcionar, administrar ou gerir seus órgãos, será submetido à lei do local de sua constituição"63. Saliente-se que esse raciocínio não ofende os dispositivos da Constituição Federal, já analisados, uma vez que estes adotam simultaneamente os critérios da constituição e da sede social efetiva.

\section{Lei aplicável e nacionalidade de sociedades no direito internacional}

Vislumbra-se uma farta quantidade de Tratados e Convenções internacionais e regionais que tratam da lei que se deve aplicar às pessoas jurídicas, muitas vezes dispondo também sobre nacionalidade. Infelizmente, em razão dos limites desse estudo, mostra-se inviável uma vasta análise das mais diversas normas convencionais. Contudo, em razão da importância do tema, convém aqui destacar algumas delas, a fim de ilustrar como a matéria vem sendo tratada na seara convencional.

Primeiramente, destaca-se o Tratado de Direito Comercial de 1889, celebrado em Montevidéu. Em seu artigo $4^{\circ}$, prevê que o "contrato social se rege tanto em sua forma como quanto às relações jurídicas entre os sócios e entre a sociedade e terceiros, pela lei do país em que ela tem seu domicílio comercial”. Essa disposição é complementada pelo art. $5^{\circ}$, ao prescrever que "as sociedades ou associações que tenham caráter de pessoa jurídica serão regidas pela lei do país de seu domicílio; serão reconhecidas de pleno direito como tais nos Estados e consideradas habilitadas para exercer neles os direitos civis e reivindicar seu reconhecimento perante os tribunais" (sistema declaratório). ${ }^{64}$

Em segundo lugar, cita-se o Tratado de Direito Comercial Terrestre Internacional de Montevidéu, de 1940, que em ser art. $8^{\circ}$ prevê:

as sociedades mercantis serão regidas pelas leis do Estado de seu domicílio comercial; serão reconhecidas de pleno direito nos outros Estados contratantes e serão consideradas habilitadas para exercer os atos de comércio e comparecer em juízo.

A disposição supra é complementada pelo art. $9^{\circ}$, ao prescrever que "as sociedades ou corporações de um tipo desconhecido pelas leis de outro Estado, podem neste exercer atos de

\footnotetext{
PAULS, Manfred, Op. cit., pp. 91-92.

${ }^{64}$ DOLINGER, Jacob. Op. cit., p. 441.
} 
comércio, desde que se submetam às prescrições legais" (sistema atributivo). Observa-se que o princípio utilizado pelos Tratados de Montevidéu é o do domicílio comercial, que, conforme seu art. $3^{\circ}$, "é o lugar onde o comerciante ou a sociedade comercial têm o lugar principal de seus negócios". Portanto, o critério adotado foi o do centro de negócios. Como exemplo de países que ratificaram esses dois tratados, cita-se a Argentina, Paraguai e Uruguai. ${ }^{65}$

O Código de Bustamante (1928), que não poderia deixar de ser citado, refere-se expressamente à nacionalidade das pessoas jurídicas, apresentando, no entanto, diferentes critérios para os distintos tipos de pessoas jurídicas. A respeito, Jacob Dolinger comenta:

\begin{abstract}
as corporações, fundações e associações terão a nacionalidade de origem determinada pela lei do Estado que as autorize ou aprove - critério da incorporação (artigos 16 e 17); o artigo 18 dispõe que as sociedades civis, mercantis ou industriais terão a nacionalidade estipulada na escritura social (critério da autonomia da vontade) e, em sua falta, onde tenham habitualmente a sua gerência ou direção principal (critério da sede social) e em dispositivo específico para as sociedades anônimas, artigo 19, dispõe que o Código que sua nacionalidade será determinada pelo contrato social (autonomia da vontade) e, eventualmente, pela lei do lugar em que normalmente se reúna a junta geral de acionistas ou, em sua falta, pela do lugar onde funcione o seu principal Conselho administrativo ou Junta diretiva. ${ }^{66}$
\end{abstract}

Outro documento de reconhecida importância é o Tratado de Roma de 1957, que instituiu a Comunidade Econômica Europeia. Em ser art. 58, dispõe que:

As companhias ou firmas constituídas de conformidade com a legislação de um Estado-membro, e tendo sua sede estatutária, sua administração central ou seu principal estabelecimento dentro da Comunidade, são equiparadas, para aplicação das disposições do presente capítulo, às pessoas físicas nacionais dos Estadosmembros.

Como se verifica, esse artigo reconhece implicitamente a personalidade da sociedade que adquiriu a nacionalidade de um dos países-membros da Comunidade (sistema declaratório), exigindo ainda, em seu art. 220, que os demais Estados adotem medidas necessárias para garantir o reconhecimento recíproco das sociedades.

Cumpre, ademais, mencionar a Convenção do Banco Internacional para Reconstrução e Desenvolvimento (BIRD). O Banco Mundial possui um Centro Internacional para a Solução de Divergências Relativas a Investimentos entre os Estados e Nacionais de outros Estados. A Convenção permite, de certa maneira, a adoção do critério do controle, caso seja essa a vontade das partes. Isso porque:

(a) Convenção dispõe que ocorrendo uma divergência entre determinado Estado e uma pessoa jurídica que tenha a nacionalidade deste Estado, mas cujo controle seja exercido por interesses estrangeiros, se pode admitir que as partes acordem considerar a pessoa jurídica como nacional de outro Estado para fins de submeter a divergência ao Centro de Solução do BIRD. ${ }^{67}$

\footnotetext{
65 Idem, p. 442.

${ }^{66}$ Ibidem.

${ }^{67}$ DOLINGER, Jacob. Op. cit., pp. 446-447.
} 
Por fim, cite-se as duas Convenções das Conferências Especializadas Interamericanas sobre Direito Internacional Privado (CIDIPs), elaboradas pela Organização dos Estados Americanos (OEA). Primeiramente, em 1979, aprovou-se a Convenção sobre Conflitos de Leis Relativas a Companhias Comerciais. Após, em 1984, foi a vez da Convenção sobre Personalidade e Capacidade das Pessoas Jurídicas no Direito Internacional Privado. Ambas as Convenções foram ratificadas pelo Brasil, sendo promulgadas, respectivamente, pelos Decretos $n^{\circ} 2.400 / 97$ e no $2.427 / 97$.

As Convenções adotaram o critério da incorporação. $\mathrm{Na}$ forma do art. $2^{\circ}$ da Convenção de 1979, “a existência, capacidade, atividade, operação e dissolução das companhias comerciais será regida pela lei do lugar de sua constituição". Em sua alínea 2a , dispõe que a lei do lugar da constituição é "a lei do Estado onde se cumprem os requisitos de forma e de fundo necessários para a criação de tais sociedades". Ademais, em seu art. $3^{\circ}$, reconhece que as sociedades constituídas em um Estado serão reconhecidas pelos demais $(\text { sistema declaratório })^{68}$.

A Convenção de 1984 seguiu método semelhante ao dispor, em seu art. 2ª , que "a existência, a capacidade para ser titular de direitos e obrigações, o funcionamento, a dissolução e a fusão das pessoas jurídicas de caráter privado serão regidos pela lei do lugar de sua constituição"69.

\section{O Processo emblemático Barcelona Traction, Light and Power, Limited}

Expostos os principais aspectos da nacionalidade e do conflito de leis em matéria de sociedades, mister trazer à baila o famoso caso Barcelona Traction, Light and Power, Limited (Bélgica v. Espanha) $)^{70}$, julgado pela Corte Internacional de Justiça (CIJ) em 1970.

Barcelona Traction, Light and Power, Limited (doravante Barcelona Traction) era uma sociedade anônima constituída em 1911, na cidade de Toronto, segundo as leis canadenses. Seu principal objeto era desenvolver o sistema de produção e distribuição de energia elétrica da Catalunha (Espanha). Para esse propósito, foram criadas várias subsidiárias, algumas com registro no Canadá, outras na Espanha. Alguns anos após a

\footnotetext{
${ }^{68}$ PAULS, Manfred, Op. cit., p. 101.

${ }^{69}$ Ibidem.

70 O julgamento na íntegra está disponível no sítio eletrônico da Corte Internacional de Justiça, pelo link

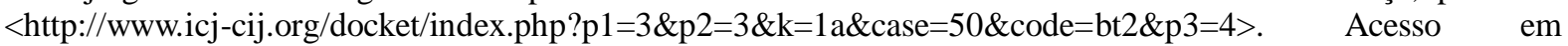
25.04.2015.
} 
Primeira Guerra Mundial, o capital da sociedade havia passado para o controle dos acionistas belgas $^{71}$. Em decorrência da política restritiva espanhola aplicada ao desenvolvimento e atividades da sociedade, a Barcelona Traction teve sua falência decretada em 12 de fevereiro de 1948, por uma Corte da Província de Terragona. A Corte determinou a apreensão dos bens da sociedade e de duas de suas subsidiárias, sendo posteriormente essa medida estendida para as demais. Novas ações foram emitidas para as subsidiárias, que foram vendidas em 1952, em um leilão público, para a recém-criada Fuerzas Electricas de Cataluña, S.A..

Alegando que a falência foi motivada por atos e omissões da Espanha, os governos da Inglaterra, Canadá, Estados Unidos e Bélgica fizeram representações contra o governo espanhol. Em 1958, a Bélgica, com o propósito de oferecer proteção diplomática aos seus acionistas, ingressou com uma ação na Corte Internacional de Justiça, pretendendo que a Espanha pagasse uma indenização, em razão dos prejuízos causados.

Com o objetivo de permitir acordos, a Bélgica desiste da ação em 23 de março de 1961, sendo seu pedido homologado em 10 de abril de 1961. Com a frustração das negociações, o governo belga ajuíza nova ação na CIJ em 19 de junho de 1962. A Espanha se defende com quatro objeções preliminares, merecendo especial destaque a alegação de que a Bélgica não possuía o jus standi, uma vez que não tinha legitimidade para defender uma sociedade canadense, simplesmente pelo fato de seus acionistas possuírem nacionalidade belga. A alegação foi aceita pela Corte Internacional de Justiça, o que levou ao indeferimento do pedido do governo belga em 5 de fevereiro de 1970. De acordo com CIJ, apenas o governo canadense possuía legitimidade ativa para exercer a proteção diplomática e reivindicar indenização no caso, uma vez que a Barcelona Traction era uma sociedade de nacionalidade canadense. Consagrou-se, assim, a adoção do critério da incorporação para reconhecer a nacionalidade a uma determinada sociedade. O julgamento foi proferido por quinze votos a um, sendo apenas o juiz ad hoc Riphagen, indicado pela Bélgica, favorável ao governo belga.

Embora não seja o escopo do trabalho analisar decisões proferidas por Tribunais brasileiros, antes de serem apresentadas as conclusões da pesquisa, é importante mencionar que, em 2004, o Superior Tribunal de Justiça apreciou o caso de uma sociedade brasileira que celebrou contrato de financiamento junto a uma sociedade com sede na República do Panamá. A matriz desta sociedade, no entanto, era no Japão. Em decorrência de Convenção para evitar bitributação, celebrada entre Brasil e Japão (promulgada pelo Decreto $n^{\circ}$ 61.889/67), a

\footnotetext{
${ }^{71}$ Esta era a alegação do governo belga; no entanto, o governo espanhol contestava alegando que a Bélgica não havia comprovado a nacionalidade dos acionistas.
} 
sociedade brasileira, ao realizar uma remessa de juros ao exterior, recolheu impostos sob alíquota reduzida, sendo, posteriormente, autuada pela Receita Federal. A União entendeu que as remessas de juros foram realizadas para a filial da sociedade japonesa do Panamá, razão pela qual seria inaplicável ao caso a Convenção. O Recurso Especial foi interposto pela sociedade brasileira contra decisão do Tribunal Regional Federal da $4^{\text {a }}$ Região, que havia acolhido a tese da União, reconhecendo que o fato da financiadora ser filial de sociedade japonesa não lhe retirava a personalidade jurídica (aplicação do art. 11 da LINDB). A análise da submissão da financiadora às leis nipônicas infelizmente esbarrou no óbice da Súmula $n^{\circ} 7$ do STJ, tendo a Corte centrado seu pronunciamento em questões tributárias, concluindo que o recorrente não havia demonstrado que os juros seriam também tributados pelas leis japonesas, razão pela qual não seria aplicável a Convenção ${ }^{72}$.

\section{CONCLUSÃO}

Ao longo do trabalho buscou-se analisar os principais critérios existentes para conferir nacionalidade às sociedades e eleger a lei aplicável a suas relações jurídicas. Iniciou-se com os conceitos básicos envolvidos na matéria, isto é, pessoa jurídica, personalidade jurídica, empresa e sociedade empresária. Feito isso, demonstrou-se que, em razão do hodierno cenário globalizado, a tendência mundial está no sentido do reconhecimento da personalidade jurídica das sociedades estrangeiras, não sendo diferente a opção do ordenamento brasileiro.

Ato contínuo, investigou-se o conceito de nacionalidade e os principais critérios adotados pelos Estados, buscando, após, demonstrar que uma leitura sistemática do ordenamento brasileiro leva à conclusão que o critério adotado para atribuição de nacionalidade brasileira a uma sociedade é o da incorporação cumulado com o da sede social efetiva. Releva destacar que foi uma opção digna de elogio, pois consegue minimizar os inconvenientes dos critérios puramente aplicados, como, por exemplo, a possibilidade de fraude por escolha abusiva do lugar de constituição da sociedade.

Passou-se então à análise dos critérios que indicam a lei aplicável à relação jurídica das sociedades e qual foi a opção do ordenamento brasileiro. Percebe-se que o art. 11, caput, da LINDB, é uma importante norma sobre matéria, que adota puramente o critério da incorporação. No entanto, seu parágrafo $1^{\circ}$ estipula que, se uma sociedade estrangeira tiver

\footnotetext{
${ }^{72}$ Cf. BRASIL Superior Tribunal de Justiça. Segunda Turma. Recurso Especial n, 457228-PR. Relator Min. Castro Meira. Julg, em 18/03/2004, publicado no DJ de 02/08/2004 p. 342.
} 
interesse de estabelecer "filiais, agências ou estabelecimentos" no Brasil, terá que requerer a autorização governamental que, uma vez deferida, sujeitará a referida sociedade às leis brasileiras. Importa destacar que essa situação não se confunde com a nacionalidade da sociedade, haja vista que ela permanece sendo estrangeira.

Por fim, apresentou-se caso emblemático na jurisprudência internacional, a fim de chamar a atenção do leitor sobre importância prática do tema. É evidente que não se pretendeu exaurir um assunto tão interessante e importante neste trabalho, mas apenas apresentar as bases de uma questão que precisa ser cada vez mais estudada, em atenção às crescentes demandas de um mundo globalizado.

\section{REFERÊNCIAS}

AMARAL, Francisco, Direito Civil. Introdução, 4. ed. Rio de Janeiro: Renovar, 2002. ARAÚJO, Nádia de. Direito internacional privado: teoria e prática brasileira. Rio de Janeiro: Renovar, 2003.

BATIFFOL, Henri. Droit International Privé. 4. ed., n. 192. Paris: L.G.D.J., 1967.

BULGARELLI, Waldirio. Sociedades comerciais. 10. ed. São Paulo: Atlas, 2001.

CARMEN, Tiburcio; BARROSO, Luís Roberto. Direito Constitucional Internacional. Rio de Janeiro: Renovar, 2013.

CASTRO, Amílcar de. Direito internacional privado. 6. ed. Rio de Janeiro: Forense, 2008.

CRISTIANO, Romano. A Nacionalidade da Empresa e a Nova Constituição Federal. In: Revista dos Tribunais, n. ${ }^{\circ}$ 639, p. 46-50. São Paulo, 1989.

DINIZ, Maria Helena. Lei de Introdução ao Código Civil Brasileiro Interpretada. 6. ed. atualiz. São Paulo: Saraiva, 2000.

DOLINGER, Jacob. A Sociedade Anônima Brasileira - Critério determinador de sua Nacionalidade. In: Revista de Direito Mercantil, Industrial, Econômico e Financeiro, n. ${ }^{\circ}$ 23, pp. 65-70. São Paulo, 1976.

_. Direito Internacional privado: parte geral. 4. ed. atualiz. Rio de Janeiro: Renovar, 1997. 
EMENDÖRFER NETO, Victor. A Nacionalidade das Corporações: Estudo do vínculo entre os Estados e os entes econômicos no contexto das relações internacionais. Disponível em: <http://www.conpedi.org.br/manaus/arquivos/anais/brasilia/16_624.pd f>. Acesso em: 20.03.2015.

ESPINOLA, Eduardo; ESPINOLA FILHO, Eduardo. Lei de Introdução ao Código Civil Brasileiro. 2. ed, atualizada por José Silva Pacheco. Rio de Janeiro: Renovar, 1995. v. 3.

FERREIRA, Lier Pires; BORGES, Marcos Aurélio dos Santos. Empresas estrangeiras e o direito ao desenvolvimento: uma análise jurídica da política de conteúdo local no setor petrolífero nacional. In: Marilda Rosado de Sá (Org.). Direito internacional dos investimentos. Rio de Janeiro: Renovar, 2014, pp. 477-498.

GONÇALVES, Carlos Roberto. Direito Civil Brasileiro. 8. ed., São Paulo: Saraiva, 2010. v. 1.

LAUTERPACHT, Elihu; GREENWOOD, Christopher; LEE, Karen (editors). International Law Reports: Annual Digest and Reports of Public International Law Cases 1941-1942, vol. 10. Reino Unido: Cambridge University Press, 1994.

JO, Hee Moon. Moderno Direito Internacional Privado. São Paulo: LTR, 2001.

MAZEAUD, Henri; MAZEAUD, Léon; MAZEAUD, Jean. Leçons de droit civil.. Paris: Ed. Montchrestien, 1969. v. 1, t. 1.

MICHEL, Keith. War, terror and carriage by sea. London: LLP, 2004.

MORAES, Alexandre de. Direito constitucional. 26. ed. São Paulo: Atlas, 2010.

NAPOLITANO, Carlo José. A Nacionalidade das Sociedades Empresariais. Disponível em: < http://www.aedb.br/seget/arquivos/artigos08/114_A_NACIONALIDADE_DAS_ SOCIEDADES_EMPRESARIAIS.pdf >. Acesso em 07.04.2015.

NIBOYET, Jean-Pierre. Traité de Droit International Privé Français. Paris: Recueil Sirey, 1950.

PAULS, Manfred. A nacionalidade e a lei aplicável à pessoa jurídica de direito privado. Disponível em: <http://dominiopublico.mec.gov.br/download/teste/arqs/cp008 701.pdf>. Acesso em 25.03.2015. 
MIRANDA, Francisco Cavalcanti Pontes de. Tratado de direito privado. 3. ed. Rio de Janeiro: Borsoi, 1954/1956. v. 1.

RECHSTEINER, Beat Walter. Direito internacional privado: teoria e prática. 15. ed., rev. e atualiz. São Paulo: Saraiva, 2012.

RÉGNIER, Leonardo Medeiros. Nacionalidade das sociedades comerciais. Curitiba: Juruá, 2002.

REQUIÃO, Rubens. Curso de Direito Comercial. 26. ed. São Paulo: Saraiva, 2005. v. 1.

RODAS, João Grandino. Sociedade Comercial e Estado. São Paulo: Saraiva, 1995.

SANTOS, Theophilo de Azeredo. Da nacionalidade das sociedades comerciais. Belo Horizonte: Imprensa Universitária da Universidade de Minas Gerais, 1957.

. Regime Jurídico das Sociedades Comerciais. Rio de Janeiro: Forense, 1958.

SILVA, Américo Luís Martins da. A ordem constitucional econômica. Rio de Janeiro: Lumen Juris, 1996.

SZTAJN, Raquel. Teoria Jurídica da Empresa: Atividade Empresária e Mercados. 2. ed. São Paulo: Atlas, 2010.

TEIXEIRA, Egberto Lacerda. A Nacionalidade e as Sociedades comerciais no Brasil e no Estrangeiro. In: Revista dos Tribunais no 420, p. 20-37. São Paulo, 1970.

VAGTS, Detley F.; DODGE, William S.; KOH, Harold Hongju. Transnational Business Problems, 4th ed. University Casebook Series, Thomson/Foundation Press, 2008.

VALLADÃO, Haroldo. Direito Internacional Privado. 5. ed. Rio de Janeiro: Freitas Bastos, 1980.

WALD, Arnold. Curso de direito civil brasileiro. Introdução e parte geral. 9. ed. São Paulo: Saraiva, 2002. v. 1.

XAVIER, Mônica Antão. Internacionalização de empresas e o direito internacional dos investimentos. In: RIBEIRO, Marilda Rosado de Sá (Org.). Direito internacional dos investimentos. Rio de Janeiro: Renovar, 2014, pp. 303-328. 